\title{
O PROBLEMA DAS METÁFORAS NA CLÍNICA
}

\author{
THE PROBLEM OF METAPHORS IN THE CLINIC
}

\author{
Bruno Vasconcelos de Almeida* \\ Denise Viuniski da Nova Cruz ${ }^{* *}$ \\ Solange Puntel Mostafa ${ }^{* * *}$
}

\begin{abstract}
RESUMO:
Este artigo problematiza o uso das metáforas na clínica médica e no ensino da clínica, extrapolando a questão para outros encontros terapêuticos, e destacando a importância da linguagem para as práticas de cuidado em saúde. Para isso, apresenta dois argumentos teóricos diferentes a respeito da metáfora, figura de linguagem tão significativa para diferentes áreas de conhecimento: argumentos contrários à utilização das metáforas resgatados do texto clássico de Susan Sontag - Doença como metáfora. AIDS e suas metáforas, e uma teorização poética favorável às metáforas como forma de expressão e representação de sentimentos de dor e de perda no pensamento de Anatole Broyard Intoxicated by my Illness and Other Writings on Life and Death. Esses dois resgates teóricos são utilizados para demonstrar a relevância do problema para a prática da clínica. O artigo concentra-se na questão linguística e na literalidade no pensamento de Gilles Deleuze, alçando as metáforas ao domínio dos conceitos filosóficos.
\end{abstract}

PALAVRAS-CHAVE: Metáforas. Filosofia. Deleuze. Clínica. Literalidade.

\section{ABSTRACT:}

This article discusses the use of metaphors in the medical clinic and clinical teaching, extrapolating the issue to other therapeutic meetings, and highlighting the importance of language for health care practices. For this, it presents two different theoretical arguments about metaphor, a figure of language so significant for different areas of knowledge: arguments against the use of the metaphors rescued from the classic text of Susan Sontag Disease as Metaphor. AIDS and its Metaphors, and a poetic theorizing favorable to metaphors as a form of expression and representation of feelings of pain and loss in the thought of Anatole Broyard - Intoxicated by my Illness and Other Writings on Life and Death. These two theoretical rescues are used to demonstrate the relevance of the problem to clinical practice. The article focuses on the linguistic question and the literalness in Gilles Deleuze's thinking, raising metaphors to the domain of philosophical concepts.

KEY WORDS: Metaphors. Philosophy. Deleuze. Clinic. Literality.

\footnotetext{
* Pós-Doutor em Filosofia (UFMG, 2016; UFMG, 2014). Doutor em Psicologia Clínica (PUC-SP, 2010). Professor do Departamento de Psicologia da PUC Minas. Professor Colaborador do Programa de Pós-Graduação em Comunicação Social da PUC Minas (PPGCOM PUC MINAS). Pesquisador do Núcleo de Estudos do Pensamento Contemporâneo (NEPC-FAFICH-UFMG). E-mail: brunovasconcelos@ pucminas.br.

** Doutora em Educação pela UNIVALI-SC, PDSE King's College, Londres. Professora de Clínica Médica, UNIVALI, SC. E-mail: denisenovacruz@gmail.com.

*** Pós-doutora em Filosofia da Educação. Professora livre-docente do Curso Ciências da Informação, USPRibeirão Preto. E-mail: smostafa@ terra.com.br.
} 


\section{INTRODUÇÃO}

Os sintomas da doença nada mais são do que uma disfarçada manifestação do poder do amor; toda doença é uma paixão transformada. Thomas Mann (A montanha mágica).

Este artigo pretende situar o problema das metáforas na prática e no ensino da clínica. O cenário clínico específico é o da clínica médica. Contudo, pretendemos extrapolar os conceitos apresentados para a clínica como um todo, para as relações entre equipes de cuidado em saúde e seus pacientes. Em trabalho acadêmico recentemente defendido (NOVA CRUZ, 2015), buscou-se demonstrar a potência das narrativas na clínica, construindo o conceito de Narrativa-Afeto. Ora, se as narrativas (literárias ou de vida - de pacientes e de médicos) têm a potencialidade imanente de afetar a ética, a prática e o ensino da clínica médica, abordamos também a questão da linguagem.

Até que ponto a linguagem, com suas funções e suas figuras, carrega em si (ou no seu fora) potência de afetar o vivido e vice-versa, isto é, o vivido como produtor de novas linguagens, no caso em questão da clínica - tanto no seu aspecto de prática, quanto em sua vocação pedagógica? Inicialmente, em sua tese de doutorado, a pesquisadora apontou dois pressupostos teóricos sobre as metáforas. O ponto de vista de Sontag (2007), em seu livro A doença como metáfora, no qual a autora visita a epistemologia das metáforas na relação entre a medicina e o doente, apontando os perigos da utilização não pensada delas diante de doenças estigmatizantes. Por outro lado, Broyard - paciente e literato -, defende com força poética a utilização das metáforas por pacientes e médicos como uma forma potente de expressão de sentimentos de dor e de perda tão presentes na prática clínica. Neste artigo, revisamos tais pressupostos e incluímos uma revisão do significado das metáforas na filosofia de Gilles Deleuze.

A metáfora em si pode compor o universo discursivo de forças esmagadoras, como no caso da estigmatização; ou, ao contrário, permitir as construções de linguagem que emancipam o paciente de seu atoleiro subjetivo, quando mergulhado na doença. Por diversas vezes, Deleuze posicionou-se contra as metáforas. Sempre insistiu que, ao falar filosoficamente, o fazia de forma literal, sem metáforas. Entretanto, são conhecidas as inúmeras ocorrências de metáforas ao longo da extensa e frutífera obra de Deleuze, seja em textos de sua autoria, seja nas parcerias filosóficas estabelecidas com seu intercessor Félix Guattari. 
Para ilustrar esse aparente paradoxo - usar muitas metáforas e se dizer absolutamente contra elas -, lembremos de alguns conceitos muito conhecidos de Deleuze e Guattari tais como rizoma, ou agenciamentos maquínicos ou o sorriso do gato de Alice. O que exatamente Deleuze pensou ao fazer uso dessa figura de linguagem posicionada na literalidade? Eis a questão.

Ao fazer filosofia, Deleuze utiliza a linguagem não de forma impensada, casual, inocente. Ciente das funções agenciadoras de propriedades linguísticas específicas, Deleuze faz uso da linguagem para fazer sentido filosófico - para criar conceitos filosóficos, para instaurar um plano de imanência para acomodar tais conceitos, para resolver problemas, para fazer movimentos absolutos do mundo. Eis, então, a relação entre a linguagem (e o seu fora), os conceitos filosóficos e a vida. A relação entre o pensamento filosófico e a forma de expressão, a escrita poética ou literária é fundamental na filosofia deleuziana, assim como foi para Nietzsche com seus aforismos e linguagem poética. A forma literária e os conceitos filosóficos formam um conjunto indissociável no pensamento desses autores, por isso a relevância de compreender o sentido da crítica deleuziana às metáforas para acessar a profundidade dos conceitos construídos e poder apropriarmo-nos deles para a prática e o ensino da clínica. Aliás, experiência na qual também pensamento, afeto e linguagem são elementos inseparáveis de construção das relações e dos encontros.

O pensamento acerca das relações entre metáforas e os processos saúde e doença equipara-se ao pensamento em torno das relações entre clínica e subjetividade, ou, ainda, entre literatura e subjetividade. A invenção de si expressa pela linguagem manifesta-se na relação com a vida, com a dor, com o sofrimento, com a alegria, com as potências magmáticas da vida. Não seria o caso de se perguntar se é possível pensar por meio da literatura? Nesse caso, as metáforas não jogariam o jogo imanente dos fluxos desejantes que percorrem os corpos de pacientes ou de escritores?

Na primeira parte do artigo, buscaremos situar o problema. Por que as metáforas são um problema na relação entre médicos e doentes? De que forma a utilização de metáforas nas narrativas - literárias ou de vida - pode afetar a prática (e o ensino) da clínica? Elas afastariam o clínico da língua viva do paciente? Como uma espécie de manto ou capa protetora, a metáfora pode funcionar como corte nos fluxos desejantes. Essa figura de linguagem traz alegria ou tristeza para médicos, pacientes e todos os envolvidos nas relações complexas que se desenrolam na prática clínica diária. Isso posto, revisamos a polêmica 
intelectual que se instalou em torno desse aparente paradoxo teórico deixado praticamente sem explicação por Deleuze no transcorrer de seu percurso filosófico.

Debate intelectual, especialmente transcrito e publicado em 2005 na revista Educação \& Sociedade, em um dossiê dedicado à intercessão entre Deleuze e a Educação. Nessa ocasião, três dos maiores conhecedores da filosofia de Deleuze apresentaram pressupostos a respeito das metáforas e literalidade na filosofia deleuziana. No entanto, parece-nos que quem melhor apresenta a importância dessa questão para inúmeras áreas do conhecimento - aliás, para a vida -, é a professora Annita Costa Malufe em artigo publicado em 2012, intitulado Aquém ou além das metáforas: a escrita poética na filosofia de Deleuze. São com esses argumentos teóricos que juntados a nossas próprias experiências de vida e de elucubração teórica que pretendemos ressaltar a importância conceitual de um uso muito singular das metáforas na teoria e na prática do ensino e da vivência da clínica médica.

\section{CONTRA AS METÁFORAS NA CLÍNICA}

O termo metáfora foi conceituado já por Aristóteles (1991, p. 273): “A metáfora consiste no transportar para uma coisa o nome de outra, ou do gênero para a espécie, ou da espécie para o gênero, ou da espécie de uma para a espécie de outra, ou por analogia”. É a figura de linguagem que substitui um termo por outro por conta de uma suposta analogia entre ambos.

Um dos principais textos contemporâneos a respeito das metáforas na clínica médica foi escrito em duas partes - separadas por uma década - pela intelectual norte-americana Susan Sontag (1991). A primeira parte trata das diferentes metáforas utilizadas por médicos, por pacientes e pela literatura para duas aflitivas situações clínicas: câncer e tuberculose. A segunda parte é dedicada às metáforas escolhidas para acompanhar a nova doença recémvislumbrada pela medicina, quando de sua publicação: a AIDS. O argumento principal de Sontag é que as doenças não são metáforas, e que o uso impensado dessa figura de linguagem pode trazer em si mais sofrimento, ou sofrimentos desnecessários, para a pessoa que está diante do desafio existencial imposto pela doença, seja câncer, tuberculose ou AIDS.

Para Sontag (1991, p.3), encarar as doenças como elas são, diretamente, "[...] de uma forma mais pura, mais resistente ao pensamento metafórico", seria uma forma mais "saudável" de lidar com a doença. Apesar disso, a própria autora admite que "[...] nós não 
podemos pensar sem metáforas" (1991, p. 91), o que, ironicamente, explica o parágrafo de abertura de seu primeiro ensaio:

\begin{abstract}
A doença é o lado sombrio da vida, uma espécie de cidadania mais onerosa. Todas as pessoas vivas têm dupla cidadania, uma no reino da saúde e outra no reino da doença. Embora todos prefiram usar somente o bom passaporte, mais cedo ou mais tarde cada um de nós será obrigado, pelo menos por um curto período, a identificarse como cidadão do outro país. (SONTAG, 1991, p. 3).
\end{abstract}

Sontag discorre como metáforas utilizadas social e historicamente - repetidas na literatura e utilizadas por médicos para seus pacientes fragilizados -, detêm o poder de estigmatizar ou piorar a situação delicada em que o paciente se encontra. Por exemplo, as metáforas bélicas tão utilizadas para significar câncer, tanto do ponto de vista causal quanto terapêutico: guerra contra o câncer, quimioterapia como arma poderosa para combater inimigo violento; inimigos, invasores, batalhões e seus canhões.

Ela lembra como as metáforas construíram, histórica e literariamente, o estigma de leveza, de poesia, de paixão e de romantismo para as vítimas da tuberculose - consumption (SONTAG, 1991, p. 31), enquanto, no extremo contrário, doentes portadores de hanseníase aliás agentes etiológicos muito parecidos -, carregam até hoje o estigma de pestilência, ojeriza, repulsão, muito, argumenta Sontag, por conta das metáforas utilizadas para representar as doenças. A metáfora do poeta tuberculoso, a face de Keats jovem, apaixonado, consumido pela doença, tossindo e escarrando sangue e compondo versos tão lindos! As metáforas da tuberculose construíram ideias de inspiração, de criatividade. Metáforas que criaram o mito da boemia, inventaram a premência de viajar a lugares longínquos e exóticos (SONTAG, 1991). O que bem demonstra o poder de tais metáforas.

O lado ruim do uso de metáforas na clínica médica é trazido por Sontag quando ela demonstra o caráter "punitivo" que algumas metáforas carregam quando buscam explicações psicológicas ou outras transcendentais para explicar a causalidade de doenças graves como o câncer (SONTAG, 1991). Já não basta para o doente ter câncer, ainda precisa carregar consigo a culpa. No caso da língua portuguesa, e durante um certo período histórico, foi bastante comum a recusa à nomeação da doença. Em especial no caso do câncer, pacientes referiam-se a ele como "a doença"; recusa ao mesmo tempo que metáfora superlativa da condição de doente. Nesse caso, o não falar equipara-se ao recobrir com metáforas e, portanto, distanciar o paciente ou o crítico de sua relação com a crueldade de sua condição clínica. 
Com o aparecimento da AIDS, a partir da década de 1980, as metáforas já existentes para a sífilis e outras doenças sexualmente transmissíveis, ao lado de valores sociais e morais vigentes, ajudaram a criar o estigma que persegue os portadores do vírus da imunodeficiência e os doentes de AIDS. "Praga é a principal metáfora pela qual a epidemia de AIDS é conhecida" (SONTAG, 1991, p. 130) e traz em si o caráter de ser infligido a alguém como forma de punição. Muito do sofrimento desses pacientes advém do julgamento moral que acompanha a criação e a afirmação das metáforas aplicadas. Como afirma Sontag (1991, p. 59), “[...] nada é mais punitivo do que dar um sentido à doença”.

Lembramos de um caso, atendido por um de nós, no qual uma portadora do vírus HIV, consciente de sua situação médica - ela própria ativista de uma associação que atua na defesa dos direitos dos portadores e doentes -, afirmava problematicamente: “Além de ser portadora do vírus, ainda sou culpada pela minha condição?”. Sua fala de resistência indicava a linha de fuga da condição estigmatizante. O fato é que, como reconhecido por Sontag (1991) e Broyard (1992), não há pensamento sem metáfora, como expressa DeBaggio (2002), diante da impotência e da inexorabilidade de uma doença como Mal de Alzheimer: "A combinação de remédios e vitaminas é tudo o que a ciência médica pode fazer por mim quase 100 anos após a descrição científica da doença. Me parece uma armada fraca para defender contra estes destroyers vorazes por memória que trabalham em meu cérebro" (DEBAGGIO, 2002, p. 9).

Como resume Frank (1995, p. 136): “Metáforas podem ser meios poderosos de levar à cura. Mas, metáforas generalizadas, oferecidas como modelos de estórias para as narrativas de outras pessoas, são perigosas”. Acompanhando Frank, podemos indagar se a metáfora não cria possibilidades distintas, dependendo do uso e do manejo: por um lado, ela impõe um processo de singularização criativa que libera as forças da vida; por outro, ela lança o sujeito no campo das generalizações, onde atuam forças moralizantes, capturadas em formas de vida sem vitalidade. Assim teríamos uma pergunta ética: $\mathrm{O}$ que pode a metáfora ou, dito de outra forma, o que pode o indivíduo na sua relação com a invenção metafórica de linguagens?

Ensinar aos alunos e aos médicos residentes o poder da metáfora e a potência da narrativa parece ser a lição alcançada por essa teorização; reconhecer nas narrativas a presença das metáforas, tanto nas dos próprios médicos, especialmente nas decorrentes do encontro com o paciente. Como afirma Sontag (1991, p. 99), citando Nietzsche, "[...] o [meu] objetivo era evitar sofrimento desnecessário [...] acalmar a imaginação". "Considerar câncer como se fosse apenas uma doença - uma doença muito grave, mas somente uma doença. Não 
uma maldição, não uma punição, não um constrangimento. Sem significado." (SONTAG, 1991, p. 100).

Já fazendo uso de uma metáfora, quando extrapolamos os conceitos da Sociologia para a relação médico-paciente e para a clínica médica, concordamos com Maffesoli quando este reconhece nessa figura de linguagem a potencialidade de " [...] perceber o aspecto matizado de um mundo marginal cujos desdobramentos ainda são imprevisíveis" (MAFFESOLI, 1998, p. 147).

\section{A FAVOR DAS METÁFORAS NA DOENÇA}

Inúmeras poderiam ser as narrativas de doentes e de médicos sobre seus pacientes que seriam capazes de fazer elogio à utilização de metáforas na clínica médica. Diversos filmes e muitos textos contam histórias de grandes padecimentos, de coragem inusitada, de novos estilos de vida, de vitórias, de desgraças, de vida e de morte. Escolhemos um único exemplo de como as metáforas têm sido utilizadas nesse campo da clínica dedicado às narrativas de pacientes portadores de doenças degenerativas ou em fases finais de doenças oncológicas.

Anatole Broyard, um crítico literário inspirado e poético, faz uma apologia a sua condição de doente terminal. Ele consegue notar, em seus últimos dias de vida, uma força não antes percebida. Para dar voz aos sentimentos envolvidos em sua experiência com a doença e o final de vida, ele faz uso de uma linguagem poética, uma narrativa poética, na qual ressalta a importância das metáforas para expressão de afetos, sensações e sentimentos difíceis de serem verbalizados ou postos por escrito. No inglês original o livro se chama Intoxicated by my illness, e o trecho a seguir pretende demonstrar o argumento de Broyard (1992) a favor do uso - por médicos e pacientes - de metáfora significativas:

Inside every patient there's a poet trying to get out.

O meu médico ideal seria capaz de "ler" minha poesia, minha literatura. Ele veria como minha doença me purificou, enfraquecendo minhas partes piores e fortalecendo as melhores. Eu não vejo qualquer razão pela qual médicos não devam ler um pouco de poesia como parte de sua formação. Morrer e adoecer é um tipo de poesia. É como um desarranjo. Na crítica literária se fala sobre um desarranjo dos sentidos. Isto é o que acontece ao homem que adoece. Então, me parece que os médicos poderiam estudar poesia para entender estas dissociações, estes desarranjos, isto traria uma maior aproximação (more total embracing) à condição do paciente.

[...] Eu queria que meu médico entendesse que debaixo da superfície alegre, eu sinto o que Ernest Becker chamou de "pânico inerente à criação" e a "sucção do infinito". 
[...] Meu médico ideal lembraria Oliver Sacks. Eu posso imaginar Dr. Sacks entrando na minha condição, olhando em volta como o proprietário de uma casa, com o locatário, tentando ver como ele transformou o imóvel em um lugar mais habitável. Ele andaria em volta, me segurando pela mão, e ele iria imaginar como seria ser eu. E então, ele iria tentar encontrar alguma vantagem nesta situação. Ele consegue transformar desvantagens em vantagens. Dr. Sacks veria a genialidade da minha doença. Ele iria compor seu daimon com o meu. E nós iríamos encarar meu destino juntos [...]. Para o médico típico, minha doença trata-se de um incidente rotineiro em um de seus rounds, enquanto que para mim é a crise da minha vida. Eu me sentiria melhor se eu tivesse um médico que ao menos percebesse essa incongruência. Eu não peço que ele me ame - de fato, e até acho que o papo do amor é muito exagerado por muitos que escrevem sobre doença [...].

$\mathrm{O}$ doente chegou a um ponto onde o que ele mais quer das pessoas não é amor mas uma compreensão crítica da sua situação, o que é conhecido na literatura como "testemunha empática" [...]. Não vejo razão ou necessidade que o meu médico me ame - nem eu espero que ele sofra comigo. Eu não exigiria muito tempo do meu médico: eu somente desejo que ele se instale (breed) na minha situação por talvez cinco minutos, que ele me entregue completamente seu pensamento uma só vez, que ele fique colado a mim por um breve instante, examine minha alma e minha carne, alcance minha doença, por que cada homem é doente de sua própria maneira.

Eu penso que o médico pode manter sua postura técnica e ainda assim se movimentar na arena humana. $\mathrm{O}$ médico pode usar sua ciência como um tipo de vocabulário poético ao invés de usá-lo como uma peça de maquinaria, de forma que o jargão possa se tornar jargão de uma espécie de poesia. Eu não vejo por que ele tenha que deixar de ser médico e se tornar um ser humano leigo. Muitos médicos sistematicamente evitam contato. Eu não espero que meu médico soe como Dr. Oliver Sacks, mas eu espero alguma vontade de fazer contato, alguma sugestão de disponibilidade. (BROYARD, 1992, p. 410, tradução nossa).

Broyard (1992, p. 20) - o paciente - afirma: “[...] contar uma estória parece ser uma reação natural à doença. As pessoas sangram estórias, e eu me tornei um banco de sangue cheio delas". "Talvez, [insiste Broyard (1992, p. 18),] [...] somente as metáforas possam expressar a perplexidade, o pânico combinado com beatitude, da pessoa ameaçada".

Não pensamos sem usar metáforas, não podemos pensar sem usar metáforas, especialmente quando doentes, como alerta Broyard (1992, p. 18). Para ele, existem sim as metáforas ruins, talvez como as apontadas por Sontag, mas existem as "aspirinas literárias", como Anatole Broyard literariamente refere-se às metáforas às quais pacientes agarram-se para enfrentar suas doenças e seus maiores temores.

A favor das metáforas, como das narrativas de uma maneira geral, conta o processo e movimento de criação no gesto de elaborar com palavras o mal de que se sofre, como no verso famoso de Virgílio: e a dor, se forma longa e difícil, abre uma brecha para as palavras. Pensar, talvez, que as metáforas não distanciam o paciente de sua condição, mas que recriam a vida sobre a condição do doente, mais ou menos como o arquiteto que resolve construir em 
um terreno de terra ruim e gastos elevados para tornar a construção viável. Dali pode sair uma construção que modifica completamente a paisagem. Se eu digo: "estou doente, e os raios de sol aquecem minha alma", reconheço minha condição e chamo o corpo de alma, ou, ainda, afirmo que o sol me aquece. A favor da metáfora, portanto, uma composição que me libera de mim, que emancipa, que cria uma linha de fuga.

O lado ruim da metáfora está ligado a uma leitura tradicional que vincula sintoma e linguagem, reduzindo o sujeito ao seu universo discursivo. A favor da metáfora, parte-se de uma outra teorização que faz das palavras criadas e ressignificadas o plano de liberação das forças que aprisionam o sujeito na doença.

Seria possível pensar que a criação metafórica pode alcançar o patamar de alegria ativa ou mesmo beatitude? A mais bela invenção do doente, tal como Klossovski (2000) caracteriza o pensamento de Nietzsche?

\section{DELEUZE E AS METÁFORAS-LITERAIS}

Como afirmado anteriormente, a escrita para Deleuze faz-se de maneira inseparável à filosofia. Existe um pressuposto recíproco entre a forma de escrever e a forma de pensar. Essa é a conclusão mais acurada que permite discorrer sobre o aparente paradoxo do pensamento filosófico de Gilles Deleuze. Ora, se ele se diz tão contrário às metáforas, como insiste - sem explicações ou longas considerações - em diversos momentos de sua vida ${ }^{1}$, por que seus textos estão repletos de conceitos e relações metafóricas? Porque, como iremos argumentar, as metáforas para Gilles Deleuze são literais, isto é, imanentes àquilo que querem dizer. Exatamente a figura proposta, não sua relação com algo outro, algo transcendente à linguagem utilizada.

A crítica de Deleuze à metáfora está calcada no seu aspecto representativo; a metáfora representa uma coisa no lugar de outra. Deleuze, ao contrário, está interessado na linguagem como produção imanente. Trata-se da coisa viva em si, sem representação, crua, vital, com a

\footnotetext{
${ }^{1}$ Conforme nota de Zourabichvili (2005, p. 1320): “'Falamos literalmente' (Deleuze; Guattari, 1998, p. 26); Deleuze; Guattari, 1999, p. 74: ‘(...) falo literalmente’; Deleuze, 1999, p. 255: '(...) reencadeamento sobre a imagem literal'; Deleuze, 1999, p. 220: 'É preciso falar e mostrar literalmente (...)'; Deleuze, 2003, p. 199: 'Todas as imagens são literais, e devem ser consideradas literalmente'. Cf. também a aula de 17 de maio de 1983 ('Falar é falar literalmente, 'eu falo literalmente', 'é preciso falar literalmente'), a aula de 15 de janeiro de 1985 ('Se vocês falarem e mostrarem, vocês falarão e mostrarão literalmente, ou então simplesmente não mostrarão. Ou será literal, ou não será nada'; 'falo literalmente ou simplesmente não falo'; 'O que isto quer dizer, este 'tudo é literal?' Tudo é tomado ao pé da letra"'. Para as aulas, veja: <www.webdeleuze.com>. Acesso em: 10 jul. 2017.
} 
violência própria da natureza, transposta para o plano da vida. A língua com seu poder de cortar a carne e o corpo, englobando em um mesmo plano ontológico os homens, as máquinas e os animais. Se saio do silêncio, torna-se necessário inscrever a linguagem na pedra, no corpo, qualquer que seja, e não remetê-la a alguma outra coisa. É o sentido ético do silêncio que nos lança na linguagem.

De outra maneira seria, como salienta Malufe (2012), como se a verdade lançasse mão de uma linguagem "verdadeira", e a retórica (seja como literatura, ou como filosofia) ocupasse um território ornamental, falso, poético, não verdadeiro. Se, dessa forma, o estatuto de texto legítimo seria o científico, aquele que contém verdades indubitáveis e que para sua representação faz pouco - ou evita - o uso das figuras de linguagem, consideradas retóricas, imaginárias, figuradas ou ficcionais, essa lógica “[...] parece legitimar um campo em detrimento do outro, como se um fosse um campo próprio da verdade e o outro seu campo figurado" (MALUFE, 2012, p. 186). Ora, o uso das metáforas como tal, como figura de linguagem que utiliza uma palavra no sentido da outra, por esta conter uma relação representacional, legitima este par maniqueísta de verdade/inverdade; real/figurado.

O jogo do falso e do representacional vale-se das estratégias do poder. O discurso científico empurra a criação literária para o campo do metafórico e do retórico. Tal problema já tinha sido apontado por Snow (1985), em um texto de grande impacto na década de 1950. O descompasso entre as "duas culturas", a cultura como tal e a cultura técnica, apontada por Snow, é retomado por Simondon (1958): são os esquemas da imaginação criadora humana que antecipam o meio que tornará possível o funcionamento dos objetos técnicos. A metáfora encontra-se exatamente no campo da criação, e, por isso, ela pode ser literal, visceral, encarnada no corpo e na matéria da vida. Impregnadas do magma da vida, as palavras deixam de ser metáforas? Adquirem sua literalidade?

Como se de um lado houvesse o território próprio da palavra (verdadeiro) e do outro oposto ou apartado - houvesse a metáfora (não verdadeira, não pertencente, intrusa ou figurada). Se afirmamos que a menina tem um coração de pedra ou que o moço é forte como um touro, aceitamos, de imediato, que há um campo, ou planos diferentes separados entre si; sendo um destes verdadeiro, real, legítimo e que, entre ambos, há um “[...] conceito abstrato que garante a relação entre esses dois planos” (MALUFE, 2012, p. 187). Relação estabelecida por algum termo abstrato, não contido no plano verdadeiro da ideia sensível. O terceiro excluído que remete o relacional ao estado, a Deus, a uma instância outra que não o próprio processo. O processo é o devir das entidades atuais. (WHITEHEAD, 1985). 
Assim, metáfora como figura de linguagem, para que possamos compreender o novo conceito sugerido por Deleuze, pressupõe dois campos paralelos e excludentes. Metáforas que tomam algo por outra coisa, que substituem termos de um plano, de uma ideia por outros relacionados de alguma forma abstrata, advindos de um plano outro, transcendente ao campo da ideia original. Para enfatizar, metáforas, usadas dessa forma, insistem em domínios transcendentes ao real. Como se a linguagem empurrasse para fora dela, ou para fora da imanência da existência, analogias, relações, possibilidades.

Então, para Deleuze que comemorava a imanência mais pura de Espinosa, não há nada em outro plano transcendente. A linguagem para Deleuze deve ser clara, uma só, imanente: “Ou você fala literalmente ou você não fala nada.” (DELEUZE, 1992).

Durante o II Colóquio Franco-Brasileiro de Filosofia da Educação no Rio de Janeiro, em novembro de 2004, dedicado ao estudo da obra de Deleuze em sua interface com a Educação, nada menos que três dos maiores especialistas da área dedicaram suas conferências ao tema da literalidade em Deleuze. François Zourabichvili (2005, p. 1309) é o primeiro a insistir em uma "compreensão ao pé da letra" e sua importância para que a imanência (da linguagem) passe a ser uma marca de uma certa maneira de se fazer filosofia. Não há, na obra de Deleuze, uma separação entre pensamento e linguagem ou entre linguagem e sua filosofia. "Porque fazer, em filosofia, não tem outro elemento a não ser a linguagem: trata-se de uma mudança de prática da linguagem" (ZOURABICHVILI, 2005, p. 1312). Por isso, a insistência da literalidade de suas expressões, de suas ideias, mesmo de usas metáforas. Tudo ao pé da letra, tudo literal, nada metafórico. Rizoma é rizoma, o cérebro é uma erva, as linhas são de fuga e são trens em marcha e os agenciamentos são maquínicos. Isto, literalmente isto Tudo na imanência da linguagem, tudo na imanência da existência. Como explica Zourabichvili (2005, p. 1311), “[...] a literalidade é o motivo de uma pedagogia interna à filosofia, de uma pedagogia propriamente filosófica".

Pelbart insiste nessa mesma lógica, salientando que o uso das metáforas funciona no "jogo de tabuleiro" da linguagem distribuindo peças de maneira correta, maneira que devemos respeitar "[...] sob pena de cairmos num sentido figurado, na metáfora, na ficção, ou simplesmente no disparate" (PELBART, 2005, p. 1327). A literalidade para Peter Pal Pelbart torna-se a condição mesma de possibilidade de conexão entre o atual e o virtual “[...] liberando o pensamento da subordinação à recognição, e abrindo-o para uma experimentação outra, um exercício livre de figuração". (PELBART, 2005, p.1327). Trata-se da criação do novo, de um pensamento novo, ditado por uma nova linguagem, na qual o par construído 
entre o verdadeiro e o figurado deixa de existir dependente de uma relação suprassensível. Não há mais par literal/metafórico. É tudo ao pé da letra, novas criações linguageiras para novos conceitos de filosofia.

Ainda, Tomaz Tadeu (2005) discute, no mesmo colóquio, essa questão e procura "uma via alternativa" ao pensamento de Zourabichvili e Pelbart. Tadeu salienta que Deleuze somente sugeriu a importância da literalidade na sua filosofia. Nunca chegou a explicitar ou explicar, como fazem os autores supracitados, a relação direta entre o uso literal das palavras e seus conceitos filosóficos. Para Tomaz Tadeu - lançando mão de uma metáfora - cabe a nós, estudiosos dos textos deleuzianos, a função de "egiptólogos, condenados a decifrar signos" (TADEU, 2005, p. 1333). Assim, com a liberdade de um pensador com olhos de arqueólogo, Tadeu lembra que se a metáfora pressupõe - enquanto figura de linguagem - uma analogia, uma semelhança entre os termos; a literalidade supõe uma "operação material, supõe um isomorfismo, uma equivalência de funcionamento, uma equivalência pragmática" (TADEU, 2005, p. 1335). Parece-nos, apesar do ceticismo de Tadeu, quando questiona as afirmações de Pelbart e Zourabichvili, que é exatamente esta a importância do (novo) uso literal de expressões, termos, palavras que, dentro dessa nova equivalência pragmática, querem significar algo novo. Algo até antes impensado. Algo que por ser impensável na imanência do pensamento foi sempre representado metaforicamente por relações transcendentes que mantinham ideia e afeto (por exemplo) em domínios excludentes. Para Deleuze, pensar e falar, escrever e fazer filosofia fazem parte do mesmo plano de imanência. Novos conceitos exigem nova linguagem, "acoplamentos inéditos" (ZOURABICHVILI, 2005), "uma continuidade de engates inesperados" (MALUFE, 2012, p. 189).

\section{PARA CONCLUIR, MAIS UMA METÁFORA}

A verdadeira viagem da descoberta não é achar novas terras, mas ver o território com novos olhos.

(Marcel Proust)

A lógica literal exigida na escrita de Deleuze e Guattari opõe-se à lógica da representação. Esta é composta por relações de identidade, oposição, analogia e semelhança, que são, segundo Deleuze, “o quádruplo cambão da representação” (DELEUZE, 2006, p. 201).

Metáforas e metonímias são figuras de linguagem que preenchem a lógica da representação com suas analogias e semelhanças. Esses dispositivos dão-nos certo conforto 
em nosso cotidiano, pois eles nos apoiam nos processos de fixar a identidade das coisas e das pessoas, a estabelecer semelhanças, oposições e analogias. São dispositivos de simplificação de nossos encontros, como afirma Orlandi (2014), ajudando-nos a reconhecer as coisas que já conhecemos. No entanto, sempre nos surpreendemos com algo... algo inesperado, talvez incompreensível. É quando somos forçados "a pensar de outro modo", um modo novo ainda não experimentado que tem a força do espanto e do não dizível, quando parece que está tudo fora de lugar.

É o mesmo espanto que nos surpreende, às vezes, diante da obra de arte, mas também diante de várias situações do cotidiano. Félix Guattari volta-se justamente para analisar nosso convívio com o mundo por meio de um novo paradigma que ele chama de "estético". Em tal paradigma, a experiência não se resume à experiência estética como produtora da obra de arte, mas como "pragmática da relação entre discursivo e existencial, entre atual e virtual". (LAZZARATO, 2014, p. 181). É nessa pragmática que gostaríamos de nos situar para pensar as narrativas entre pacientes e médicos. Em outra oportunidade, desenvolvemos a necessidade de superar posturas fenomenológicas em favor da filosofia da diferença e sua pragmática.

As narrativas, em um olhar deleuziano, seriam casos de solução para as ideias problemáticas baseadas em relações diferenciais. Eis que, para Deleuze, o virtual é habitado por ideias sempre problemáticas que, por um processo de dramatização, se atualizam. Tais atualizações são vistas como casos de solução para a problematicidade da ideia. Defendemos, então, a necessidade de devolver as narrativas ao seu campo problemático, para ser possível tocar no mundo pré-verbal da subjetividade humana. Lá habitam as semióticas não verbais, os afetos ou as ideias não representativas. São essas relações impessoais do mundo virtual que são as mais difíceis de serem apreendidas pela linguagem comum, com ou sem metáforas. Mas, para tal, temos de nos instalar entre os ditos e não ditos, entre o discursivo e o existencial ou entre o discursivo e o não discursivo.

Existe um maquinismo em tudo o que falamos e vivemos. Nossas histórias e narrativas são sempre a tentativa de remontar nossas experiências, ultrapassando-as por assim dizer. Parece que elas sempre vão além de nós; nossas histórias narram muito mais do que dizem, não porque escondemos desejos, crenças ou a verdade-do-dizer, mas porque o sujeito e seus meios de expressão transformam-se no e através do acontecimento narrativo. Não por acaso, Nova Cruz (2015) traz às humanidades médicas o conceito de "narrativas-afeto" ou "narrativas-acontecimento", pois é no encontro entre médico e paciente que a novidade aflora para ambos. 
É sempre no entre, na terceira margem, no encontro dos corpos, através dos incorporais. É sempre no acontecimento, quando este dispara conexões capazes de aumentar a potência de viver. Vale lembrar a noção de pré-individual que encontramos em Simondon e Deleuze, campo variável de intensidades que antecede as formas individuantes. Encontramos nas narrativas pistas das dimensões sensíveis do trabalho clínico. Ao problematizarmos as metáforas neste texto, não nos prendemos às lógicas da representação. Ao contrário, busca-se problematizar possíveis sentidos por meio das criações narrativas. Não interpretamos o texto ou a fala; ao contrário, vamos ao encontro imanente com o texto ou a fala, encontro de corpos, encontro necessariamente violento que ativa as potências de vida quando da relação médicopaciente, psicólogo-paciente, ou qualquer outro trabalhador de saúde, mas especialmente no âmbito literário.

Quem é o sujeito que narra na clínica médica? Quem somos nós os autores que escrevem este texto? Em nossa intercessão com Deleuze e Guattari, saímos em busca do encontro, à espreita de algo que nos arraste para fora da recognição, da semelhança, do já visto. Pensar que estamos no encontro, na sua dimensão processual e relacional, em que não é mais possível lembrar do sujeito, esquecimento que reconfigura subjetividades.

Deleuze e Guattari (1995) perguntam pelo funcionamento dos agenciamentos, preferindo entender o sujeito como uma máquina a-significante sobre o qual não há nada a entender ou a interpretar. Nenhum significado no que dizemos, escrevemos ou narramos. Perguntar apenas pelos efeitos, pelo que podemos fazer com o que somos. Exatamente isto: buscar na narrativa a sua potência imanente.

Deleuze propôs-se desconstruir as narrativas considerando-as nas suas potencialidades de apresentar e resolver problemas, sempre na dobra, ocupado em fazer com que cada nova história ou a própria história devenha outra coisa, o tempo todo. Pensar narrativas como Acontecimento é aproximá-las de um conceito filosófico: acontecimento, o que faz aparecer suas potencialidades fora da noção de sujeito. Todas as figuras de linguagem, as metáforas, os oxímoros, as contradições, os esquecimentos, os lapsos e os acréscimos incluídos nas narrativas funcionam como uma minoração da linguagem, uma nova língua possível seguindo a proposição proustiana de falar uma língua estrangeira dentro da língua própria.

Nossa linguagem na clínica, como na vida, só será nova (poética/obra de arte) se utilizar a virtualidade da multiplicidade linguística. Por isso, a importância da relação direta entre o campo filosófico e a imanência da linguagem pré-narrativa (virtual). Como explicam Mostafa, Nova Cruz e Benevelluto (2013): 
São essas compreensões da relação entre virtual e atual que nos farão devolver as narrativas para o plano dos acontecimentos puros, dissolvendo a narrativa em seu campo problemático, fazendo-a dobrar sobre si mesma, pois o acontecimento como conceito filosófico é o contrário de uma estória ou de uma narrativa, independe da constituição do sujeito ou do tempo histórico/cronológico.

Então, se a literalidade faz parte da construção de uma pedagogia filosófica, podemos apropriar-nos desse conceito (se filosófico) - roubá-lo ou extrapolá-lo - para a questão da linguagem e o uso de metáforas na clínica? Se, para Susan Sontag, as metáforas bélicas têm a potência de aumentar o sofrimento e o estigma dos pacientes portadores de "pragas", "pestes" ou invadidos ou perseguidos por "inimigos ferozes", criando um abismo intransponível entre médicos e doentes; se, para Broyard, o uso de metáforas por médicos e pacientes pode ser a única forma de realmente compreender ou representar dor, sofrimento, perda e luto; então, talvez, a literalidade deva ser o ponto de partida para considerar o uso de linguagem metafórica na clínica.

Dizemos: "Vamos travar uma guerra contra o câncer"; pensemos - junto a Deleuze se estamos diante de tropas amigas ou inimigos ferozes? Sim? Não? Esta metáfora é minha? Do paciente? Nossa? Ou trata-se de um pressuposto imanente a minha prática terapêutica, aos meus costumes profissionais, aos meus conceitos éticos pensados? Queremos supor que utilizar metáforas com esses três pressupostos teóricos no horizonte do pensamento permite supor uma clínica imanente, ligada de forma direta ao encontro propriamente dito que se dá no dia a dia dos ambulatórios e das enfermarias. Tudo muito verdadeiro, único, singular e paradoxalmente complexo. Complexo como uma terra nova.

Gostaríamos de pensar uma relação não metafórica com a linguagem, uma relação na qual possamos comer as palavras, copular com as palavras, fagocitá-las, torná-las literais. Após meter os dentes, e isto não deveria ser uma metáfora, vê-las se transformando em outras coisas; tentar apreendê-las nos fluxos desejantes que atravessam os bons e os maus encontros, em narrativas cheias de vitalidade, mesmo quando expressam as dores e os sofrimentos do viver.

\section{REFERÊNCIAS}

ARISTÓTELES. Ética a Nicômaco. In: ARISTÓTELES. Poética. Seleção de textos de José Américo Motta Pessanha. 4. ed. São Paulo: Nova Cultural, 1991.

BROYARD, Anatole. Intoxicated by my illness and other writings on life and death. New York: Fawcet Columbine, 1992. 
DEBAGGIO, Thomas. Losing my mind: an intimate look at life with Alzheimer's. New York: The Free Pre, 2002.

DELEUZE, Gilles. Conversações. São Paulo: 34, 1992.

DELEUZE, Gilles. A ilha deserta e outros textos. São Paulo: Iluminuras, 2006.

DELEUZE, G., GUATTARI, F. Mil Platôs: capitalismo e esquizofrenia. V. 1. Rio de Janeiro: 34, 1995.

FRANK, Arthur. The wounded storyteller: body, illness, and ethics. Chicago: The University of Chicago Press, 1995.

KLOSSOVSKI, Pierre. Nietzsche e o círculo vicioso. Tradução Hortencia S. Lencastre. Rio de Janeiro: Pazulin, 2000.

LAZZARATO, Maurizio. Signos, máquinas, subjetividades. São Paulo: SESC, 2014.

MAFFESOLI, Michel. Elogio da razão sensível. Tradução de Albert Christophe Migueis Stuckenbruck. Petrópolis, RJ: Vozes, 1998.

MALUFE, Annita Costa. Aquém ou além das metáforas: a escrita poética na filosofia de Deleuze. Revista de Letras, São Paulo, v. 52, n. 2, p. 185-204, jul./dez. 2012.

MANN, Thomas. A montanha mágica. Rio de Janeiro: Nova Fronteira, 2000.

MOSTAFA, Solange; NOVA CRUZ, Denise Viuniski.; BENEVELLUTO, Felipe. Fenomenologia versus Filosofia da Diferença: a Biblioterapia em questão. DataGramaZero, Rio de Janeiro, v. 14, n. 6, dez. 13. Disponível em: <http://www.dgz.org.br/dez13/Art_03.htm>. Acesso em: 10 jul. 2015.

NOVA CRUZ, Denise Viuniski. A potência das narrativas no ensino [e na prática] da clínica médica. 2015. 199 f. Tese. (Doutorado em Educação) - Universidade do Vale do Itajaí, UNIVALI, Itajaí, 2015.

ORLANDI, Luiz. Um gosto pelos encontros. 2014. Disponível em:

$<$ http://deleuze.tausendplateaus.de/wp-content/uploads/2014/10/Um-gosto-pelos-encontrosArtigo-de-Luiz-Orlandi1.pdf>. Acesso em: 10 jul. 2015.

PELBART, Peter Paul. Solidão, fascismo e literalidade. Educação e Sociedade, Campinas, v. 26, n. 93, p. 1323-1329, set./dez. 2005.

SIMONDON, Gilbert. Du mode d'existence des objets techniques. Paris: Aubier, 1958.

SNOW, Charles Percy. As duas culturas e uma segunda leitura: uma versão ampliada das duas culturas e a revolução científica. Tradução de Geraldo Gerson de Souza e Renato de Azevedo Rezende Neto. São Paulo: EDUSP, 1985. 
SONTAG, Susan. Doença como metáfora. AIDS e suas Metáforas. São Paulo: Companhia de Bolso, 2007.

SONTAG, Susan. Illness as metaphor \& Aids and its metaphors. London: Penguin, 1991.

TADEU, Tomaz. Deleuze e a questão da literalidade: uma via alternativa. Educação e Sociedade, Campinas, v. 26, n. 93, p. 1331-1338, set./dez. 2005.

WHITEHEAD, Alfred North. Process and reality. New York: The Free Press, 1985.

ZOURABICHVILI, François. Deleuze e a questão da literalidade. Educ. Soc., Campinas, v. 26, n. 93, p. 1309-1321, set./dez. 2005. 